Available online at http://journal.stkip-andi-matappa.ac.id/index.php/histogram/index

Histogram : Jurnal Pendidikan Matematika 2 (2), 2018, 206-222

\title{
PENGEMBANGAN LKM GEOMETRI ANALITIK BIDANG BERBASIS RME UNTUK MENINGKATKAN KEMAMPUAN LITERASI MATEMATIKA
}

\author{
Sitti Busyrah Muchsin ${ }^{1}$, Rahmat Kamaruddin'², Karlina Razak ${ }^{3}$ \\ STKIP Andi Matappa ${ }^{1,2,3}$ \\ * Corresponding Author. Email: sittibusyrah@yahoo.co.id \\ Received: 1 September 2018; Revised: 21 September 2018; Accepted: 27 September 2018
}

\begin{abstract}
ABSTRAK
Penelitian ini bertujuan untuk memperoleh perangkat pembelajaran berupa Lembar Kerja Mahasiswa berbasis pendekatan Realistic Mathematics Education yang valid dan efektif untuk meningkatkan kemampuan literasi matematika mahasiswa pada mata kuliah Geometri Analitik Bidang. Proses pengembangan LKM menggunakan model 4-D Thiagarajan. Instrumen-instrumen dalam penelitian ini adalah: (1) lembar validasi perangkat pembelajaran LKM, (2) lembar observasi, (3) angket respons mahasiswa, dan (4) tes berupa pretest dan posttest yang mengukur kemampuan literasi mahasiswa pada materi Geometri Analitik Bidang. Tes ini digunakan untuk mengukur tingkat kemampuan literasi mahasiswa yang terdiri dari level 1-6 sesuai dengan framework PISA. LKM berbasis Realistic Mathematics Education yang dikembangkan divalidasi oleh dua ahli kemudian dianalisis dengan validitas isi Gregory. Hasil penelitian menunjukkan bahwa LKM yang dikembangkan dinyatakan valid dan efektif berdasarkan penilaian validator dan hasil uji coba yang dilaksanakan. Kevalidan perangkat lebih dari $75 \%$ atau V > 75\%. Ini menunjukkan bahwa LKM yang dihasilkan berada pada kategori valid atau inferensia yang dilakukan adalah sahih. Keefektifan perangkat ditunjukkan dengan terpenuhinya 3 dari 4 indikator kefektifan yang ditetapkan, antara lain: (1) Rata-rata kemampuan literasi matematika mahasiswa berada pada level "sedang" (2) terpenuhinya 7 dari 9 kategori aktivitas siswa, (3) Semua mahasiswa memberikan respon positif sebesar 100\% dari tiap aspek yang direspon.
\end{abstract}

Kata kunci: Pengembangan LKM, RME, Literasi Matematika

How to Cite: Muchsin, S, B., Kamaruddin, K., \& Razak, K. (2018). Pengembangan LKM Geometri Analitik Bidang Berbasis $R M E$ untuk Meningkatkan Kemampuan Literasi Matematika. Histogram: Jurnal Pendidikan Matematika, 2(2), 207-221. doi: http://dx.doi.org/10.31100/histogram.v2i2.241

Permalink/DOI:

http://dx.doi.org/10.31100/histogram.v2i2.241

\section{PENDAHULUAN}

Pelajaran matematika bertujuan agar peserta didik memiliki kemampuan memahami konsep matematika, menggunakan penelaran, memecahkan masalah, mengkomunikasikan gagasan, dan memiliki sikap menghargai kegunaan matematika dalam kehidupan (Permendiknas No. 22 Tahun 2006). Tujuan tersebut sejalan dengan aspek-aspek kemampuan literasi matematika. Pada draf assessment framework PISA 2012 
diartikan sebagai kemampuan seseorang individu untuk merumuskan, menerapkan, dan menafsirkan matematika dalam berbagai konteks, termasuk kemampuan melakukan penalaran secara matematis dan menggunakan konsep, prosedur, fakta, dan alat matematika untuk menggambarkan, menjelaskan atau memperkirakan fenomena/kejadian. Sedangkan menurut Stacey (2011), literasi matematika diartikan sebagai kemampuan seseorang individu merumuskan, menggunakan, dan menafsirkan matematika dalam berbagai konteks, termasuk di dalamnya bernalar secara matematis dan menggunakan konsep, prosedur, fakta, dan alat matematika dalam menjelaskan dan memprediksi fenomena.

Literasi matematika sangat penting dimiliki oleh setiap insan, karena dapat membantu dalam menghadapi permasalahan matematis terkait dengan peran dalam kehidupan sehari-hari. Dengan kemampuan literasi matematika, seseorang dapat memahami suatu masalah, merepresentasikan secara matematis masalah yang dihadapi, dapat menyelesaikan masalah tersebut serta dapat menyampaikan gagasan matematis terkait dengan masalah matematika yang dijumpai dalam kehidupan nyata (Sugiman, 2012). Intinya, dengan kemampuan literasi matematika seseorang dapat menggunakan konsep-konsep matematika dalam menyelesaikan permasalahan yang ada.

Namun pada kenyataannya, kemampuan literasi yang dicapai mahasiswa Indonesia jauh dari memuaskan. Hasil PISA (Programme for International Student Assessment), yaitu studi tentang penilaian mahasiswa tingkat internasional tiap 3 tahun sekali terhadap kemampuan literasi mahasiswa berusia 15 tahun dalam membaca, matematika, dan sains menunjukkan pada PISA 2006, Indonesia berada pada urutan 50 dari 57 negara dengan skor 391. Pada pelaksanaan PISA 2009, Indonesia meraih posisi 61 dari 65 negara dengan skor 371. Sementara pada PISA 2012, Indonesia hanya mampu mencapai posisi 64 dari 65 negara dengan skor 375 (OECD, 2013).

Hal tersebut juga berdampak pada mahasiswa semester awal yang tengah menempuh pendidikan di program studi Pendidikan Matematika STKIP Andi Matappa. Pada mata kuliah Geometri Analitik Bidang, yang di dalamnya memuat kemampuan memahami unsur geometri dan kemampuan aljabar. Dari pengamatan awal yang dilakukan oleh peneliti, mahasiswa cenderung menghapal konsep matematika yang bersifat rumus dan algoritmik. Ketika diberikan permasalahan dunia nyata yang terkait konsep Geometri Analitik Bidang, mahasiswa kesulitan dalam merepresentasikannya. Hal ini tentunya disebabkan kemampuan literasi matematika yang dimiliki masih kurang. 
Histogram: Jurnal Pendidikan Matematika, 2 (2), 2018 - 208

Sitti Busyrah Muchsin, Rahmat Kamaruddin, Karlina Razak

Untuk menunjang tercapainya tujuan perkuliahan dan upaya untuk meningkatkan kemampuan literasi matematika, tidak dapat dipungkiri peran sajian bahan ajar dalam perangkat pembelajaran, khususnya dalam perencanaan dan pembelajaran matematika sangat penting dan dominan, tanpa mengesampingkan yang lain. Hal ini sesuai dengan pendapat Sahid (2009) bahwa perangkat pembelajaran matematika sebagai sumber belajar dan mengajar matematika merupakan komponen yang paling esensial.

Olehnya itu, pada mata kuliah Geometri Analitik Bidang, untuk memfasilitasi pencapaian literasi matematika mahasiswa, maka peran sajian konsep matematika dalam Lembar Kerja Mahasiswa (LKM) berbasis Realistic Mathematics Education (RME) sangat diperlukan. Kebermaknaan konsep matematika merupakan konsep utama dalam RME sehingga dalam pengaplikasiannya materi matematika disajikan dengan bertitik tolak pada konteks kehidupan sehari-hari mahasiswa. Konteks atau situasi "real" yang pernah dialami oleh mahasiswa yang merupakan jembatan untuk menghubungkan mahasiswa dari tahap real ke arah formal matematik. Filsafat RME yang dikembangkan berdasarkan gagasan atau pandangan Hans Freudenthal, yaitu: (1) mathematics must be connected to reality; and (2) mathematics as human activity" (Sembiring, Hadi, Dolk; 2008). Namun Van den Heuvel-Panhuizen dalam Wijaya (2012) mengungkap bahwa realistik yang dimaksud atau situasi kehidupan bukan hanya sebatas apa yang nyata pada pandangan mahasiswa tetapi juga semua hal yang dapat dibayangkan mahasiswa, terjangkau oleh imajinasinya.

Olehnya itu, LKM berbasis RME ini perlu dikembangkan guna menciptakan situasi dan kondisi belajar, sehingga mahasiswa aktif dalam belajar, baik secara mental, emosional, sosial maupun fisik dalam menyelesaikan masalah matematika yang bersentuhan dengan dunia nyata (realistik) sehingga mampu meningkatkan kemampuan literasi matematika mahasiswa. Salah satu model pengembangan perangkat menurut Sahid (2009) adalah Thiagarajan, dan Semmel yang disebut model 4-D (four D Models) dengan empat tahapan: pendefinisian (define), perancangan (design) pengembangan (Develop). Sehingga, permasalahan yang dikaji dalam penelitian ini dirumuskan sebagai berikut: "Bagaimana proses dan hasil pengembangan perangkat pembelajaran berupa Lembar Kerja Mahasiswa (LKM) berbasis Realistic Mathematics Education guna meningkatkan kemampuan literasi matematika pada mata kuliah Geometri Analitik Bidang yang valid dan efektif?" 
Histogram: Jurnal Pendidikan Matematika, 2 (2), 2018 - 209

Sitti Busyrah Muchsin, Rahmat Kamaruddin, Karlina Razak

\section{METODE PENELITIAN}

\section{A. Jenis Penelitian}

Jenis penelitian ini adalah penelitian pengembangan yakni pengembangan perangkat pembelajaran berupa Lembar Kerja Mahasiswa dan Tes Kemampuan Literasi Matematika.

\section{B. Setting Penelitian}

1. Waktu dan Lokasi Penelitian

Penelitian ini dilaksanakan pada semester ganjil tahun ajaran 2018/2019 pada program studi Pendidikan Matematika STKIP Andi Matappa yang beralamat di Jl. A. Mauraga No.70 Pangkajene Kabupaten Pangkep Sulawesi Selatan.

2. Subjek Penelitian

Subjek penelitian adalah mahasiswa semester III yang memprogram mata kuliah Geometri Analitik Bidang pada program studi Pendidikan Matematika STKIP Andi Matappa yang berjumlah 14 orang.

\section{Instrumen Penelitian}

Instrumen-instrumen dalam penelitian ini adalah: (1) lembar validasi perangkat pembelajaran LKM, (2) lembar observasi, (3) angket respons mahasiswa, dan (4) tes yang mengukur kemampuan literasi mahasiswa pada materi Geometri Analitik Bidang.

\section{Teknik Pengumpulan Data}

Untuk mengumpulkan data dalam penelitian ini dilakukan dengan cara sebagai berikut:

1. Data hasil validasi ahli

Untuk memperoleh data validasi dari para ahli dan praktisi dilakukan cara menyebarkan perangkat Lembar Kerja Mahasiswa yang telah dirancang untuk diberikan penilaian, saran, dan kritik. Penilaian yang diberikan oleh validasi ahli dan praktisi dengan menggunakan lembar validasi.

2. Data hasil kemampuan literasi mahasiswa

Untuk memperoleh data tentang kemampuan literasi mahasiswa diberikan pretest dan posttest yang kepada mahasiswa sebelum dan setelah pelaksanaan perkuliahan Geometri Analitik Bidang masing-masing sebanyak 6 butir soal sesuai dengan level PISA. 
Histogram: Jurnal Pendidikan Matematika, 2 (2), 2018 - 210

Sitti Busyrah Muchsin, Rahmat Kamaruddin, Karlina Razak

\section{Data aktivitas mahasiswa}

Untuk memperoleh data aktivitas mahasiswa dalam perkuliahan dilakukan pengamatan dengan menggunakan lembar observasi aktivitas mahasiswa selama proses perkuliahan berlangsung dengan lembar observasi yang digunakan telah diberikan penilaian dan dikoreksi oleh validator. Pengamat diminta untuk menuliskan nomor-nomor kategori aktivitas mahasiswa yang dominan muncul dalam setiap 5 menit (4 menit mengamati, 1 menit menuliskan nomor kategori yang muncul) mulai dari awal hingga akhir proses pembelajaran.

4. Data respons mahasiswa

Untuk memperoleh data respons mahasiswa terhadap perkuliahan Geometri Analitik Bidang yang menerapkan Lembar Kerja Mahasiswa berbasis Realistic Mathematics Education, digunakan angket respons mahasiswa yang telah direvisi berdasarkan penilaian dan koreksi dari para ahli. Angket respons mahasiswa diberikan kepada seluruh mahasiswa yang menjadi subjek penelitian. Pemberian angket tersebut dilakukan setelah berakhirnya seluruh proses perkuliahan.

\section{E. Teknik Analisis Data}

Data yang telah dikumpulkan dengan menggunakan instrumen-instrumen selanjutnya dianalisis secara kuantitatif untuk menentukan kevalidan dan keefektifan. Data yang diperoleh dari hasil validasi oleh para ahli dianalisis untuk menjelaskan kevalidan dan kelayakan penggunaan Lembar Kerja Mahasiwa yang telah dibuat. Adapun data hasil ujicoba di kelas digunakan untuk menjelaskan keefektifan.

Berikut ini dikemukakan tentang analisis data kevalidan dan keefektifan.

1. Analisis Data Kevalidan Perangkat Lembar Kerja Mahasiswa

Analisis uji kevalidan secara rasional diperoleh melalui hasil validasi para ahli terhadap Lembar Kerja Mahasiswa yang kemudian dianalisis dengan mempertimbangkan penilaian, masukan, komentar dan saran-saran dari validator. Untuk menentukan validitas isi dan reliabilitas menyeluruh dari suatu tes melalui penilaian pakar. Relevansi kedua pakar secara menyeluruh merupakan validitas isi Gregory (Ruslan, 2009), yaitu berupa koefisien validitas isi.

Koefisien validitas isi dapat dihitung dengan menggunakan rumus berikut:

$$
\text { Validitas isi }=\frac{D}{A+B+C+D}
$$


Histogram: Jurnal Pendidikan Matematika, 2 (2), 2018 - 211

Sitti Busyrah Muchsin, Rahmat Kamaruddin, Karlina Razak

Keterangan

A $\quad=$ Sel yang menunjukkan kedua penilai/pakar menyatakan tidak relevan.

$\mathrm{B}$ dan $\mathrm{C}=$ Sel yang menunjukkan perbedaan pandangan antara penilai/pakar.

D = Sel yang menunjukkan kedua penilai/pakar menyatakan relevan.

Berikut ini adalah model kesepakatan antar penilai untuk validitas isi:

Tabel 1. Model Peniliaian Validitas

Validator I

\begin{tabular}{ccc}
\hline & $\begin{array}{c}\text { Tidak relevan } \\
\text { Skor (1-2) }\end{array}$ & $\begin{array}{c}\text { Relevan } \\
\text { Skor (3-4) }\end{array}$ \\
\hline $\begin{array}{c}\text { Tidak relevan } \\
\text { Skor (1-2) }\end{array}$ & A & B \\
\hline $\begin{array}{c}\text { Relevan } \\
\text { Skor (3-4) }\end{array}$ & C & D \\
\hline
\end{tabular}

(Sumber: Ruslan, Tahun: 2009)

Untuk memutuskan apakah Lembar Kerja Mahasiswa telah memiliki derajat validitas yang memadai, maka digunakan model kesepakatan tersebut dengan kriteria hasil penilaian dari kedua validator minimal memiliki "relevansi kuat". Jika hasil dari koefisian validitas isi ini tinggi $(\mathrm{V}>75 \%)$, maka dapat dinyatakan bahwa hasil pengukuran atau interfensi yang dilakukan adalah sahih.

Namun, apabila tidak demikian maka perlu dilakukan revisi berdasarkan saran yang diberikan validator atau dengan melihat kembali aspek-aspek yang nilainya kurang. Selanjutnya dilakukan validasi ulang kemudian dianalisis kembali. Demikian seterusnya hingga data dapat dinyatakan sahih.

2. Analisis Data Keefektifan Lembar Kerja Mahasiswa

Analisis terhadap keefektifan perangkat pembelajaran yakni Lembar Kerja Mahasiswa didukung oleh hasil analisis data dari beberapa komponen keefektifan, yaitu (a) hasil kemampuan literasi matematika, (b) aktivitas mahasiswa, dan (c) respons mahasiswa. Oleh karena itu, kegiatan analisis data terhadap ketiga komponen itu adalah sebagai berikut: 
Histogram: Jurnal Pendidikan Matematika, 2 (2), 2018 - 212

Sitti Busyrah Muchsin, Rahmat Kamaruddin, Karlina Razak

a. Analisis Data Peningkatan Kemampuan Literasi Matematika

Analisis dilakukan terhadap skor-skor yang diperoleh mahasiswa dari tes yang berisi soal kemampuan literasi matematka yang memuat bebebrapa konteks dengan level yang berbeda. Level yang digunakan sesuai dengan levela kemampuan literasi matematika pada PISA. Hal ini menjadi acuan penilaian pemberian skor berdasarkan level 1-6. Selanjutnya untuk menganalisis apakah terdapat peningkatan yakni dengan menganalisis pretest dan posttest kemampuan literasi dengan menggunakan uji gain dengan rumus sebagai berikut:

$$
\text { Indeks gain }=\frac{\text { skor postest-skor pretest }}{\text { SMI-skor pretest }}
$$

b. Analisis Data Aktivitas Mahasiswa

Data hasil pengamatan aktivitas mahasiswa selama kerjasama dalam kelompok dilaksanakan, dianalisis dan dideskripsikan. Untuk mencari persentase aktivitas mahasiswa dan waktu yang digunakan, dianalisis sebagai berikut:

$$
P T a=\frac{\sum T a}{\sum T} X 100 \%
$$

Keterangan:

PTa : Persentase aktivitas mahasiswa untuk melakukan suatu jenis aktivitas tertentu.

$\sum$ Ta : Jumlah jenis aktivitas mahasiswa yg dilakukan setiap pertemuan

$\sum \mathrm{T}$ : Jumlah seluruh aktivitas mahasiswa.

Kemudian persentase aktivitas mahasiswa tersebut dibandingkan dengan rentang baik yang diperoleh dari persentase waktu ideal dengan menggunakan toleransi $5 \%$.

Persentase waktu ideal mahasiswa dalam melakukan aktivitas tertentu dihitung berdasarkan persentase jumlah alokasi waktu dari seluruh SAP pada aktivitas tertentu terhadap jumlah waktu seluruh SAP yang rumusnya sebagai berikut

$$
P w i=\frac{\sum w a}{\sum w} X 100 \%
$$

pwi : Persentase waktu ideal untuk melakukan suatu jenis aktivitas tertentu

$\sum$ wa : Jumlah alokasi waktu dari semua SAP pada aktivitas tertentu.

$\sum \mathrm{w}:$ Jumlah seluruh alokasi waktu.

c. Analisis Respons Mahasiswa

Kriteria yang ditetapkan untuk menyatakan bahwa para mahasiswa memiliki respons positif terhadap perangkat pembelajaran Lembar Kerja berbasis Realistic ISSN: 2549-6700 (print), ISSN 2549-6719 (online) 
Histogram: Jurnal Pendidikan Matematika, 2 (2), 2018 - 213

Sitti Busyrah Muchsin, Rahmat Kamaruddin, Karlina Razak

Mathematics Education pada mata kuliah Geometri Analitik Bidang adalah jika 50\% dari mereka memberi respons positif terhadap minimal 70\% jumlah aspek ditanyakan. Respon positif mahasiswa untuk aspek LKM terpenuhi.

\section{HASIL PENELITIAN DAN PEMBAHASAN}

\section{A. Hasil Tahap Pendefinisian (define)}

Tahap pendefinisian bertujuan untuk menentukan dan mendefinisikan syaratsyarat yang dibutuhkan dalam pembelajaran dengan menganalisis tujuan dan batasan materi. Tahap pendefinisan ditetapkan terlebih dahulu sebagai landasan dalam penyusunan rancangan perangkat pembelajaran yang akan dikembangkan. Kegiatan yang dilakukan dalam tahap ini adalah analisis awal-akhir, analisis mahasiswa, analisis materi, analisis tugas, dan spesifikasi tujuan perkuliahan. Kegiatan ini ditetapkan terlebih dahulu sebagai landasan untuk melangkah ke tahap-tahap pengembangan selanjutnya.

\section{B. Hasil Tahap Perancangan (design)}

Tahap ini bertujuan merancang prototipe perangkat pembelajaran. Hasil pada tahap perancangan (design) berupa instrument penelitian yaitu Lembar Kerja Mahasiswa (LKM) dan Tes Kemampun Literasi Matematika. Perangkat yang dihasilkan pada tahap perancangan (design) ini disebut draft awal. Hasil dari masing-masing kegiatan pada tahap perancangan diuraikan sebagai berikut.

\section{Lembar Kegiatan Mahasiswa (LKM)}

Pada tahap ini LKM yang dikembangkan sebanyak 4 buah untuk 4 kali pertemuan dan dirancang dalam bentuk penemuan terbimbing oleh mahasiswa tentang penerapan konsep geometri pada bidang yakni diagram kartesius, garis dan bidang serta persamaan lingkaran dan parabola. LKM berisi tentang masalah realistik kehidupan sehari-hari yang berhubungan dengan Geometri Analitik Bidang. Mahasiswa menuliskan jawaban berdasarkan hasil diskusi bersama kelompok kerja dalam mengkonstruk ide untuk menghasilkan solusi pemecahan masalah yang tepat.

\section{Tes Kemampuan Literasi Matematika}

Tes kemampuan literasi matematika terdiri dari dua tes yakni pretes dan postest. Adapun yang dikembangkan pada tahap ini adalah 6 butir soal berdasarkan level PISA yang disusun sesuai dengan kisi-kisi yang memuat indikator-indikator pencapaian. Soalsoal disusun dalam bentuk soal essay dengan tetap mengintegrasikan masalah realistik pada 
Histogram: Jurnal Pendidikan Matematika, 2 (2), 2018 - 214

Sitti Busyrah Muchsin, Rahmat Kamaruddin, Karlina Razak

instruksi soal maupun konteks soal secara eksplisit. Komponen tes hasil belajar meliputi kisi-kisi, soal tes, rubrik penskoran (kunci jawaban).

\section{Hasil Tahap Pengembangan (develop)}

Tahap pengembangan adalah merupakan tahapan ketiga dari model 4-D. Tahap pengembangan (develop) bertujuan untuk menghasilkan perangkat pembelajaran yang direvisi dan layak untuk menghasilkan diujicobakan. Kegiatan yang dilakukan pada tahap ini adalah validasi ahli dan uji coba terbatas. Hasil dari setiap kegiatan pada tahap pengembangan ini diuraikan sebagai berikut.

1. Deskripsi Penilaian Ahli Terhadap Perangkat Pembelajaran

Validator yang melakukan validasi terdiri atas 2 orang pakar/ahli. Penilaian ahli terhadap LKM dan Tes Kemampuan Literasi Matematika didasarkan pada: format, bahasa, isi, ilustrasi dan manfaat/kegunaan yang tertuang dalam instrumen lembar validasi perangkat pembelajaran. Selama proses validasi perangkat yang telah dirancang, terdapat beberapa revisi hingga akhirnya diberikan penilaian akhir.

Dari penilaian ahli (validasi) diperoleh koreksi, kritik, dan saran-saran yang selanjutnya merupakan bahan pertimbangan untuk merevisi perangkat. Hasil revisi untuk masing-masing perangkat pembelajaran tersebut diuraikan sebagai berikut.

a. Hasil Penilaian dan Hasil Revisi LKM

Tabel 2. Hasil penilaian LKM oleh dua validator

\begin{tabular}{rlccc}
\hline \multicolumn{1}{c}{ Aspek yang Dinilai } & Validator & \multirow{2}{*}{ Keterangan } \\
\cline { 2 - 3 } 1. & Format & & & \\
\hline a. & Sistem penomoran jelas & 4 & 4 & $\mathrm{D}$ \\
\hline b. & Pengaturan ruang/tata letak & 3 & 4 & $\mathrm{D}$ \\
\hline c. & Jenis dan ukuran huruf sesuai & 4 & 4 & $\mathrm{D}$ \\
\hline d. & Petunjuk penyelesaian aktivitas jelas & 4 & 4 & $\mathrm{D}$ \\
\hline 2. Isi & & & & \\
\hline a. & Kebenaran isi/materi & 4 & 3 & $\mathrm{D}$ \\
\hline b. & $\begin{array}{l}\text { Kesesuaian urutan penyelesaian masalah } \\
\text { jelas }\end{array}$ & 4 & 3 & $\mathrm{D}$ \\
\hline
\end{tabular}


Histogram: Jurnal Pendidikan Matematika, 2 (2), 2018 - 215

Sitti Busyrah Muchsin, Rahmat Kamaruddin, Karlina Razak

\begin{tabular}{cllll}
\hline \multicolumn{2}{c}{ Aspek yang Dinilai } & \multicolumn{2}{c}{ Validator } & \multicolumn{2}{c}{ Keterangan } \\
\cline { 3 - 4 } & $\mathbf{1}$ & $\mathbf{2}$ & $\mathrm{D}$ \\
\hline c. & $\begin{array}{l}\text { Kesesuaian dengan pembelajaran } \\
\text { Realistic Mathematics Education }\end{array}$ & 4 & 4 & \\
\hline d. & $\begin{array}{l}\text { LKM disertai dengan ilustrasi atau } \\
\text { gambar yang berkaitan dengan materi } \\
\text { atau konsep secara efektif }\end{array}$ & 3 & 3 & D \\
\hline
\end{tabular}

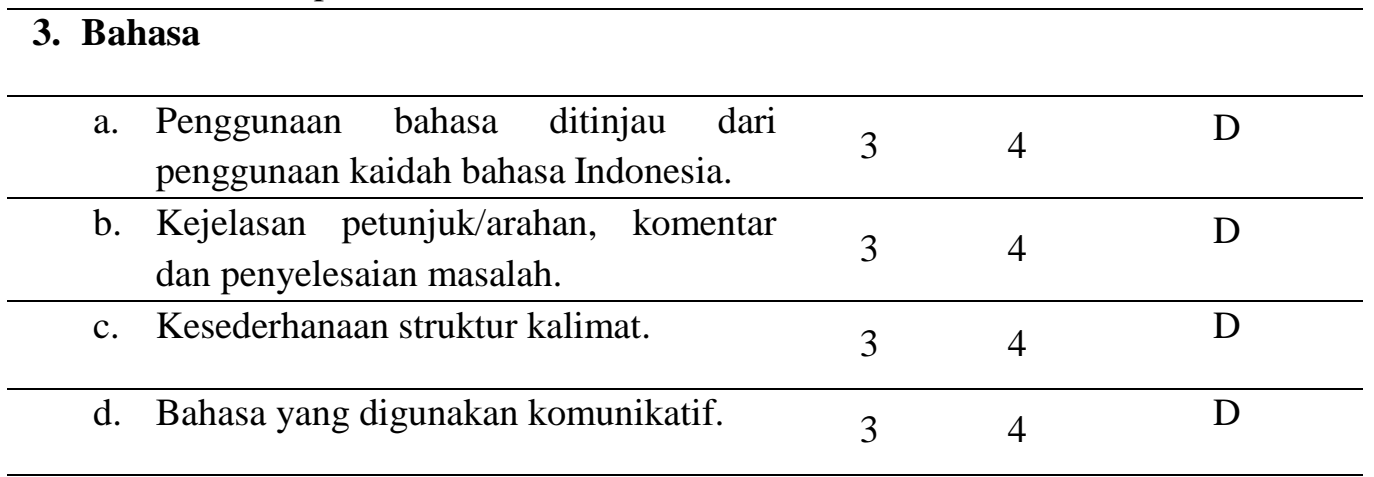

\section{Waktu}

\begin{tabular}{llll}
\hline $\begin{array}{l}\text { Rasionalitas alokasi } \\
\text { menyelesaikan LKM }\end{array}$ & waktu untuk \\
\hline
\end{tabular}

Adapun hasil analisis pada tabel di atas dapat dijelaskan sebagai berikut:

Tabel 3. Hasil Kesepakatan antar 2 pakar tentang LKM

Validator I

\begin{tabular}{ccc}
\hline & $\begin{array}{c}\text { Tidak relevan } \\
\text { Skor (1-2) }\end{array}$ & $\begin{array}{c}\text { Relevan } \\
\text { Skor (3-4) }\end{array}$ \\
\hline $\begin{array}{c}\text { Tidak relevan } \\
\text { Skor (1-2) }\end{array}$ & 0 butir & 0 butir \\
\hline $\begin{array}{c}\text { Relevan } \\
\text { Skor (3-4) }\end{array}$ & 0 butir & 13 butir \\
\hline
\end{tabular}

Dari penilaian yang diberikan oleh kedua validator di atas dapat dihitung tingkat kesahihan berdasarkan rumus validitas isi Gregory sebagai berikut:

$$
\text { Validitas isi }=\frac{13}{(0+0+0+13)}=\frac{13}{13}=1
$$

Jadi dapat disimpulkan bahwa kesahihan yang diperoleh, yaitu 1 atau $\mathrm{V}=100 \%$. Hal ini berarti, hasil penilaian kedua validator memiliki "relevansi kuat" dengan koefisian 
Histogram: Jurnal Pendidikan Matematika, 2 (2), 2018 - 216

Sitti Busyrah Muchsin, Rahmat Kamaruddin, Karlina Razak

validitas isi lebih dari 75\% atau $\mathrm{V}>75 \%$, maka dapat dinyatakan bahwa hasil pengukuran atau inferensia yang dilakukan adalah sahih.

Selama proses validasi LKM, diperoleh 2 prototipe. Hasil akhir dari validasi untuk LKM menunjukkan bahwa para validator umumnya menyimpulkan bahwa LKM yang dikembangkan valid dan dapat digunakan dengan melakukan sedikit revisi terutama pada bagian penggunaan ilustrasi atau gambar agar lebih memudahkan mahasiswa memahami konsep yang dibahas.

b. Revisi Tes Kemampuan Literasi Matematika (TKLM)

Hasil penilaian terhadap TKLM dikemukakan pada tabel di bawah ini:

Tabel 4. Hasil Kesepakatan antar 2 pakar pada lembar validasi TKLM

Validator I

\begin{tabular}{ccc}
\hline & $\begin{array}{c}\text { Tidak relevan } \\
\text { Skor (1-2) }\end{array}$ & $\begin{array}{c}\text { Relevan } \\
\text { Skor (3-4) }\end{array}$ \\
\hline $\begin{array}{c}\text { Tidak relevan } \\
\text { Skor (1-2) }\end{array}$ & 0 butir & 0 butir \\
\hline $\begin{array}{c}\text { Relevan } \\
\text { Skor (3-4) }\end{array}$ & 0 butir & 6 butir \\
\hline
\end{tabular}

Dari penilaian yang diberikan oleh kedua validator di atas dapat dihitung tingkat kesahihan berdasarkan rumus validitas isi Gregory sebagai berikut:

Validitas isi $=\frac{6}{(0+0+0+6)}=\frac{6}{6}=1$

Jadi dapat disimpulkan bahwa kesahihan yang diperoleh, yaitu 1 atau $\mathrm{V}=100 \%$. Hal ini berarti, hasil penilaian kedua validator memiliki "relevansi kuat" dengan koefisian validitas isi lebih dari 75\% atau $\mathrm{V}>75 \%$, maka dapat dinyatakan bahwa hasil pengukuran atau inferensia yang dilakukan adalah sahih

Selama proses validasi Tes, diperoleh 2 prototipe. Hasil akhir dari validasi untuk TKLM menunjukkan bahwa para validator umumnya menyimpulkan bahwa Tes yang dikembangkan valid dan dapat digunakan dengan melakukan sedikit revisi.

b. Uji Coba Perangkat Pembelajaran

Setelah draft awal direvisi berdasarkan hasil validasi maka hasil revisi tersebut kemudian diujicobakan dengan cara menggunakan perangkat tersebut di kampus tempat uji coba. Tujuan uji coba ini adalah untuk mendapatkan masukan dari mahasiswa dan 
pengamat. Hasil uji coba tersebut kemudian dianalisis. Hasil analisis tersebut selanjutnya dijadikan pertimbangan untuk melakukan revisi terhadap perangkat pembelajaran.

Kegiatan uji coba perangkat pembelajaran dilaksanakan selama 2 kali. Mahasiswa yang menjadi subjek uji coba perangkat ini adalah mahasiswa program studi pendidikan matematika 2018/2019 berjumlah 21 orang dengan kemampuan akademik yang beragam, ada mahasiswa yang berkemampuan tinggi, sedang, dan rendah. Pada pelaksanaan proses perkuliahan peneliti dibantu oleh dua observer.

Tabel 5. List Pengamat dalam uji coba perangkat pembelajaran

\begin{tabular}{cll}
\hline No. & \multicolumn{1}{c}{ Nama } & \multicolumn{1}{c}{ Keterangan } \\
\hline 1 & Karlina, S.Pd & Pengamat pengelolaan pembelajaran \\
2 & Devi Regil Apsela, S.Pd & Pengamat aktivitas siswa. \\
\hline
\end{tabular}

Uji coba dilakukan sebanyak 6 kali pertemuan mulai tanggal 27 Oktober sampai 22 September 2018. Rancangan awal perangkat pembelajaran (Draft awal) divalidasi oleh ahli. Hasil validasi ahli dijadikan sebagai bahan pertimbangan untuk merevisi perangkat pembelajaran kemudian diujicobakan di semester III pendidikan matematika STKIP Andi Matappa.

\section{c. Analisis Keefektifan Perangkat Pembelajaran}

Analisis terhadap keefektifan perangkat pembelajaran didukung oleh hasil analisis data dari beberapa komponen keefektifan yaitu (1) aktivitas mahasiswa, (2) respons mahasiswa, dan (4) ketuntasan hasil belajar. Perangkat pembelajaran efektif apabila memenuhi 3 dari 4 komponen di atas tetapi komponen kriteria ketuntasan secara klasikal harus tercapai.

1) Deskripsi Hasil Pengamatan Aktivitas Mahasiswa

Berdasarkan hasil observasi terlihat bahwa selama kegiatan pembelajaran materi geometri berbasis pendekatan RME berlangsung mahasiswa menunjukkan bahwa kategori pertama sampai kategori 9 pada setiap pertemuan berada pada rentang batas toleransi. Secara umum berdasarkan hasil analisis data aktivitas mahasiswa kelompok 3 dan 4 yang menjadi fokus pada uji coba, diketahui bahwa dari 9 jenis kategori aktivitas yang diamati semua kategori aktivitas terpenuhi. Meskipun terdapat 2 jenis aktivitas yakni kategori 
Histogram: Jurnal Pendidikan Matematika, 2 (2), 2018 - 218

Sitti Busyrah Muchsin, Rahmat Kamaruddin, Karlina Razak

aktivitas ke-8 (melakukan kegiatan di dalam tugas misalnya menunjukkan gerakan seperti sedang berpikir, melihat pekerjaan teman, dsb) dan aktivitas ke-9 (melakukan kegiatan di luar tugas misalnya misalkan tidak memperhatikan penjelasan guru, mengerjakan tugas mata pelajaran lain, atau kegiatan lain yang tidak berhubungan dengan aktivitas KMB, misalnya main, tidur dsb) tidak harus terpenuhi karena 2 kategori ini tidak termasuk kategori inti namun pada kenyataannya kategori ini juga tetap terpenuhi. Ini tidak terlepas dari peran dosen yang baik dalam mengelola pembelajaran di kelas. Data pengamatan aktivitas mahasiswa pada uji coba ini dapat dikatakan memenuhi kriteria keefektifan.

2) Deskripsi Hasil Respons Mahasiswa

Respons mahasiswa terhadap perangkat pembelajaran dibagi dalam dua aspek yaitu respons terhadap pelaksanaan pembelajaran dan respons terhadap Lembar Kegiatan Mahasiswa (LKM). Hasil analisis data respons mahasiswa terhadap pelaksanaan pembelajaran yang diisi oleh 14 mahasiswa. Ada dua aspek yang menjadi fokus respons mahasiswa terhadap kegiatan pembelajaran yang diberikan ke mahasiswa, yaitu (1) respons mahasiswa terhadap perangkat pembelajaran dan proses pembelajaran terdiri dari 18 item pernyataan, (2) respons mahasiswa terhadap lembar kegiatan mahasiswa yang terdiri dari 5 item pernyataan.

Sesuai hasil persentase dari 18 item pernyataan di atas dengan kriteria yang telah ditetapkan, maka aspek respons mahasiswa terhadap perangkat pembelajaran dan proses pembelajaran berada pada kategori "positif". Sedangkan respon mahasiswa terhadap lembar kegiatan mahasiswa adalah sesuai hasil persentase dari 7 item pernyataan di atas dengan kriteria yang telah ditetapkan, maka aspek respons mahasiswa terhadap lembar kegiatan mahasiswa berada pada kategori "positif".

Berdasarkan data analisis respon mahasiswa terhadap perangkat pembelajaran dan proses pembelajaran dan lembar kegiatan mahasiswa jika dihubungkan dengan kriteria respons mahasiswa terhadap keseluruhan komponen pembelajaran geometri analitik bidang berbasis RME untuk meningkatkan kemampuan literasi matematika adalah "positif".

3) Deskripsi Hasil Tes Literasi Matematika

Hasil analisis deskriptif skor tes literasi matematika setelah pembelajaran materi geometri menggunakan LKM berbasis RME dapat dilihat bahwa skor rata-rata hasil belajar mahasiswa semester III prodi pendidikan matematika STKIP Andi Matappa pada mata kuliah Geometri Analitik Bidang adalah sedang yakni 52,8 dari skor ideal 100. Skor Copyright (C) 2018, Histogram: Jurnal Pendidikan Matematika ISSN: 2549-6700 (print), ISSN 2549-6719 (online) 
minimum yang diperoleh mahasiswa adalah 31 dan skor maksimum yang diperoleh mahasiswa adalah 73 .

Jika skor hasil belajar yang ada dikelompokkan ke dalam kategori-kategori yang sesuai, maka diperoleh tabel distribusi frekuensi sebagai berikut:

Tabel 6. Distribusi frekuensi dan persentase skor kemampuan literasi matematika

\begin{tabular}{cccc}
\hline Skor & Kategori & Frekuensi & Persentase \\
\hline $0-34$ & Sangat Rendah & - & - \\
$35-54$ & Rendah & 3 & 21,43 \\
$55-64$ & Sedang & 8 & 57,14 \\
$65-84$ & Tinggi & 3 & 21,43 \\
$85-100$ & Sangat Tinggi & - & - \\
\hline
\end{tabular}

Dari tabel tersebut rata-rata hasil belajar berada pada interval 55 - 64. Dengan demikian, dapat disimpulkan bahwa literasi matematika berada pada kategori "sedang". Peningkatan kemampuan literasi matematika ini juga ditunjukkan dari hasil uji gain terhadap hasil pretest dan posttest mahasiswa yakni 0,51 (sedang).

Dari keempat kriteria keefektifan, pada uji coba hanya 3 aspek yang dipenuhi yaitu: aktivitas siswa, respon siswa, dan ketuntasan hasil belajar, sedangkan aspek peningkatan kemampuan literasi mahasiswa belum memenuhi kriteria. Berdasarkan kriteria keefektifan pada Bab IV dapat disimpulkan bahwa pada uji coba, perangkat pembelajaran sudah efektif karena telah memenuhi 3 dari 4 indikator keefektifan dan yang paling utama adalah indikator ketuntasan hasil belajar dapat terpenuhi.

Hasil-hasil yang diperoleh di atas mengindikasikan bahwa pada uji coba yang dilakukan, perangkat pembelajaran telah memenuhi kriteria kevalidan dan kefektifan.

\section{KESIMPULAN DAN SARAN}

\section{A. Kesimpulan}

Berdasarkan hasil penelitian yang telah diuraikan, maka dapat disimpulkan sebagai berikut.

1. Perangkat yang dihasilkan pada penelitian ini meliputi: (1) Lembar Kerja mahasiswa (LKM), dan (2) Tes Kemampuan Literasi Matematika. Hasil validasi dan uji coba 
Histogram: Jurnal Pendidikan Matematika, 2 (2), 2018 - 220

Sitti Busyrah Muchsin, Rahmat Kamaruddin, Karlina Razak

menunjukkan bahwa perangkat yang dikembangkan memenuhi kriteria kevalidan yaitu dengan besar Validitas Isi lebih dari $75 \%$ atau $\mathrm{V}>75 \%$.

2. Perangkat pembelajaran yang dihasilkan memenuhi kriteria efektif yang ditunjukkan dengan terpenuhi 3 dari 4 indikator kefektifan yang ditetapkan. Adapaun indikator yang terpenuhi yaitu pencapaian kemampuan literasi matematika, aktivitas mahasiswa, dan respon mahasiswa.

\section{B. Saran}

Penelitian yang dilakukan dengan menggunakan Lembar Kerja Matematika (LKM) berbasis Realistic Mathematics Education (RME) untuk meningkatkan kemampuan literasi matematika pada mata kuliah Geometri Analitik Bidang hanya pada satu kelas sehingga hanya hasil uji coba ini yang menjadi dasar dalam merevisi perangkat yang dikembangkan, proses penyebaran yang dilakukan hanya berupa sosialisasi pada matematika tempat penelitian dilaksanakan masih berada pada skala kecil, untuk itu beberapa saran berikut dapat menjadi acuan para peneliti selanjutnya untuk mengembangkan penelitian ini.

1. Hendaknya dilakukan uji coba dan penyebaran pada skala yang lebih luas agar memperoleh hasil yang lebih baik dalam pengembangan perangkat.

2. Diharapkan pada dosen dan calon peneliti untuk terlebih dahulu memahami kemampuan literasi yang dimiliki mahaisswa agar lebih memudahkan dalam merancang suatu proses pembelajaran dan perkuliahan. 


\section{DAFTAR PUSTAKA}

Depdiknas .(2006). Permendiknas No 22 Tahun 2006 Tentang Standar Isi. Jakarta Depdiknas.

OECD. (2013). PISA 2012 Assessment and Analytical Framework: Mathematics, Reading, Science, Problem Solving and Financial Literacy. Paris: OECD Publishing.

Ruslan. (2009). Validitas Is. Buletin Pa'biritta, 10(6), 18-19.

Sahid. (2009). Pengembangan Bahan Ajar matematika model kooperatif tipe Numbered Head Together (NHT) pada siswa kelas VII SMP Negeri 1 Sinjai Utara.Tesis. PPs Universitas Negeri Makassar.

Stacey, K. (2011). The PISA View of Mathematical Literacy in Indonesia. Journal on Mathematics Education (IndoMS-JME), 2(2),95-126.

Sugiman. (2008). Pandangan Matematika Sebagai Aktivitas Insani Beserta Dampak Pembelajarannya. Jurnal Pendidikan Matematika (Nomor 2 tahun 2008), 61-71.

Sembiring R.K., Hadi S, dan Dolk M. (2008). Reforming Mathematics Learning in Indonesia Classroom through Realistic Mathematics Education. Diakses dari http://www.springerlink.com. pada tanggal 21 Mei 2017, Pukul 22.05 WITA.

Wijaya, A. (2012). Pendidikan Matematika Realistik: Suatu Alternatif Pendekatan Pembelajaran Matematika. Yogyakarta: Graha Ilmu. 